\title{
RHEUMATOID CHANGES IN THE METACARPOPHALANGEAL REGION AS A CAUSE OF BUNNELL'S SIGN
}

\author{
BY \\ KAUKO VAINIO \\ From the Rheumatism Foundation Hospital, Heinola, Finland (Medical Director V. A. I. Laine, M.D.)
}

Positive Bunnell sign is a well-known phenomenon in rheumatoid arthritis. According to Bunnell (1953) it follows an inflammatory lesion involving the joints and soft tissues, and is not due to ischaemia as in traumatic cases.

The role of spasm and subsequent fibrosis of the intrinsic muscles has been widely discussed (Boyes, 1964; Brewerton, 1957; Goldner, 1953; Harris and Riordan, 1954; Marmor, 1962; Strang and Hueston, 1963).

Kestler (1949) found inflammatory lesions, degenerative and vascular changes, and changes in the collagen tissue in the intrinsic muscles. In severe cases the muscle fibres were replaced by connective tissue, but some workers doubt whether muscular weakness can in fact produce lasting deformities (American Rheumatism Association, Rheumatism Review Committee, 1966).

In numerous operations on patients with a positive Bunnell sign, I have never found a true spasm, which should have been easily overcome by anaesthesia. In biopsy specimens of macroscopically normal tissue, the changes mentioned by Kestler have been observed only occasionally.

The following investigations were made to clarify Bunnell's observations.

Material.-One or more of the intrinsic tendons were explored in $\mathbf{4 8}$ rheumatoid hands undergoing resectionarthroplasty of the metacarpophalangeal joints; the series thus consists of cases with severe destruction of the metacarpal heads.

Results.-Severe changes of the intrinsic apparatus were seen in fourteen hands, where the interosseus and lumbrical muscles and their tendons pass the metacarpophalangeal joint, close to the inflamed capsule.
Microscopically the specimens showed the following changes: typical rheumatoid nodule (4); tendon tissue with increased vascularity and collections of inflammatory cells (5); acute synovitis of the rheumatoid type (5).

Nodules.-Three of the nodules were in the wing tendons, and one filled the junction of the third volar interosseus and the fourth lumbrical (Fig. 1).

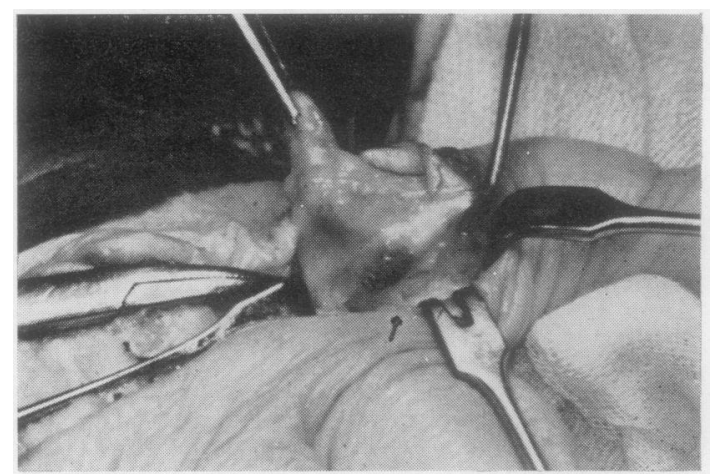

Fig. 1.-Large rheumatoid nodule at the junction of the fourth lumbrical and third volar interosseus. The muscles are soft as seen by the folding of the interosseus when pull is exerted on the nodule. by the folding of the interosseus when pull is exerted on the nodule. first phalanx of the little finger (arrow).
for theen the lumbrical muscle and tend

In the last case the articular side of the nodule consisted of inflamed synovial membrane (Fig. 2, opposite); histologically this was a typical rheumatoid nodule (Fig. 3, opposite). The histological picture was similar in the three nodules located in the wing tendons which were about the size of a pea or a bean (Fig. 4, overleaf).

Tendons.- A tendon lesion was seen in the isolated wing tendon (Fig. 5, overleaf) in the same hand as that shown in Figs 1-3.

Synovia.-It was impossible to dissect the intrinsic aponeurosis from the capsule and the synovial membrane, so that synovitis was demonstrated in only five specimens.

Different degrees of adhesions, similar to those seen 


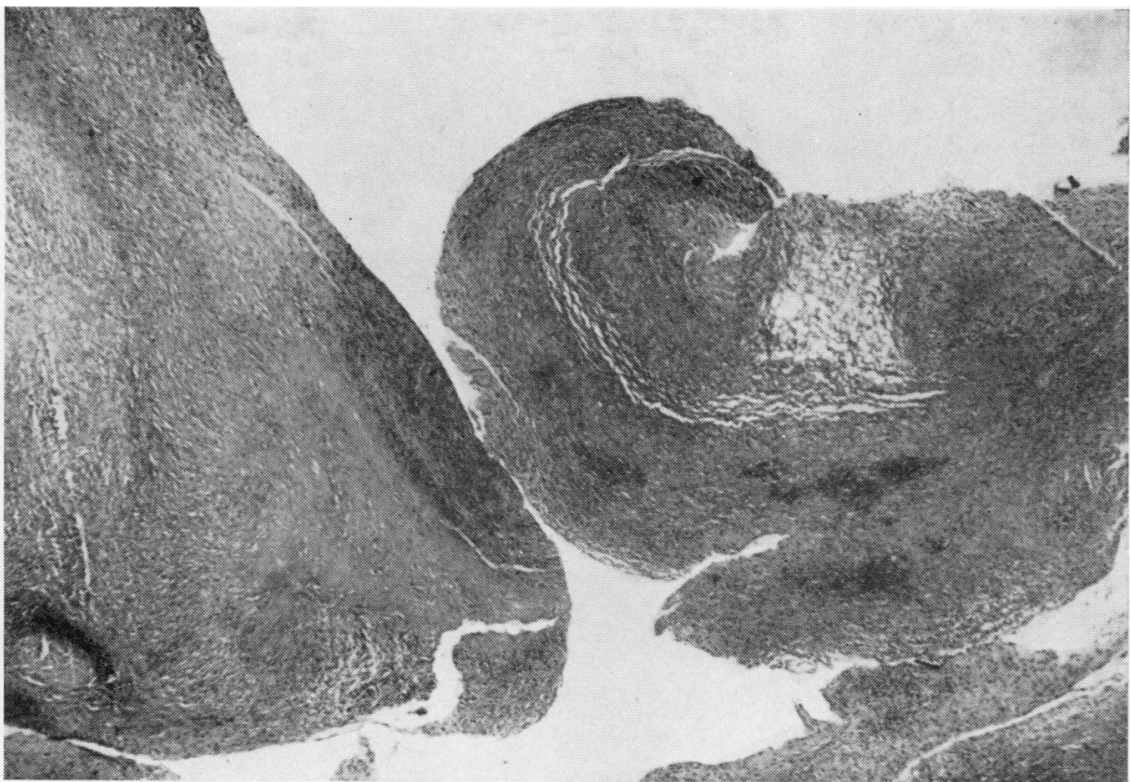

Fig. 2.-Same case as in Fig. 1. Villous synovitis on the articular
side of the specimen.

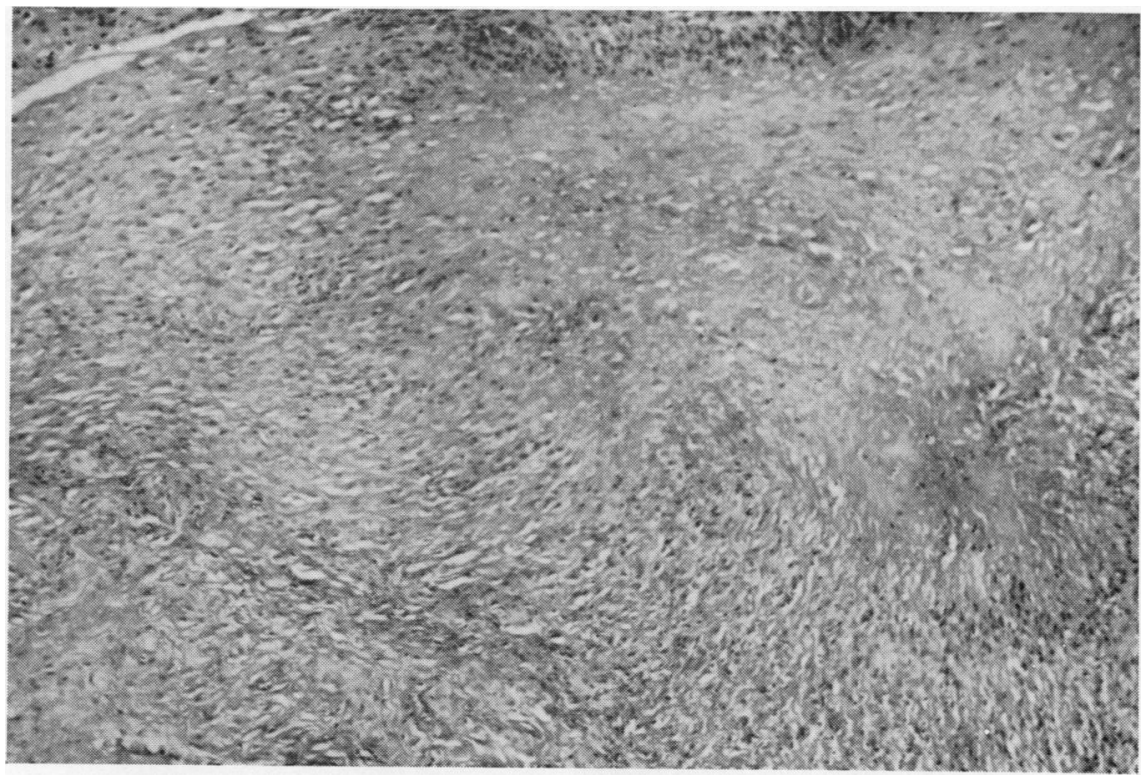

Fig. 3. - Same case as in Fig. 1. Rheumatoid nodule with central necrosis surrounded by palisading cells.

$\times 75$. 


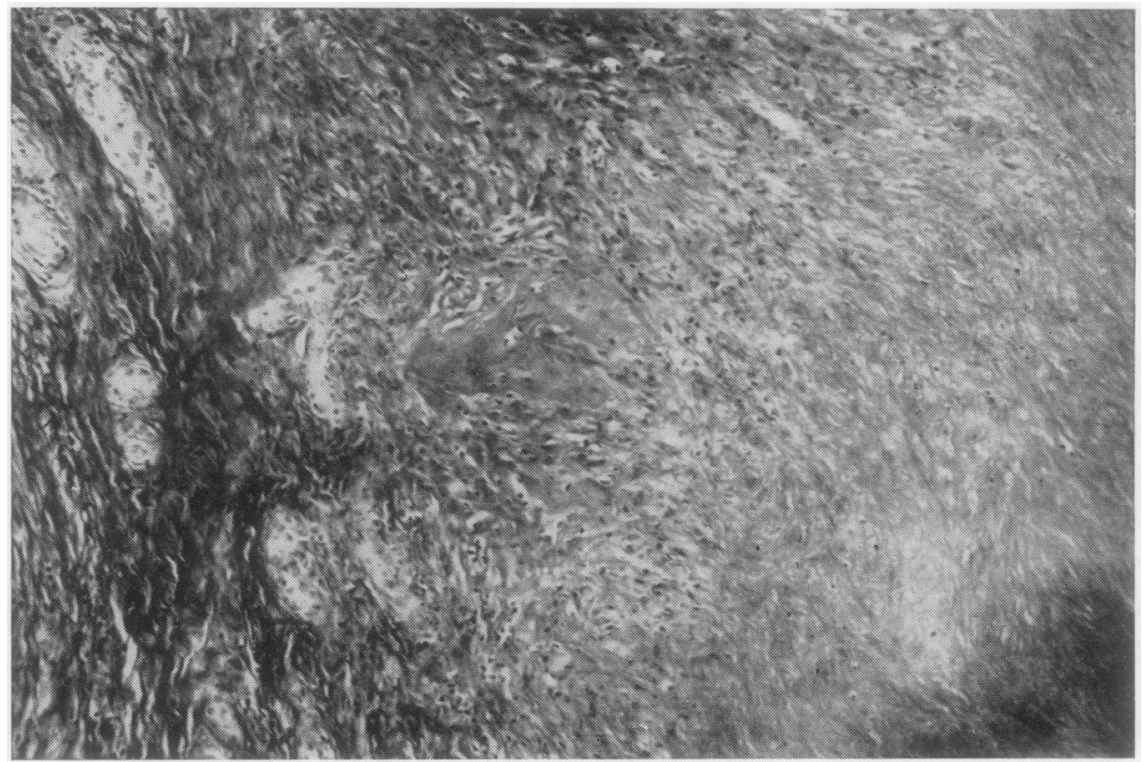

Fig. 4.- Nodule of the wing tendon. Tendon tissue with increased vascularization and diffuse inflammatory cell infiltration on the left,
nodule on the right.

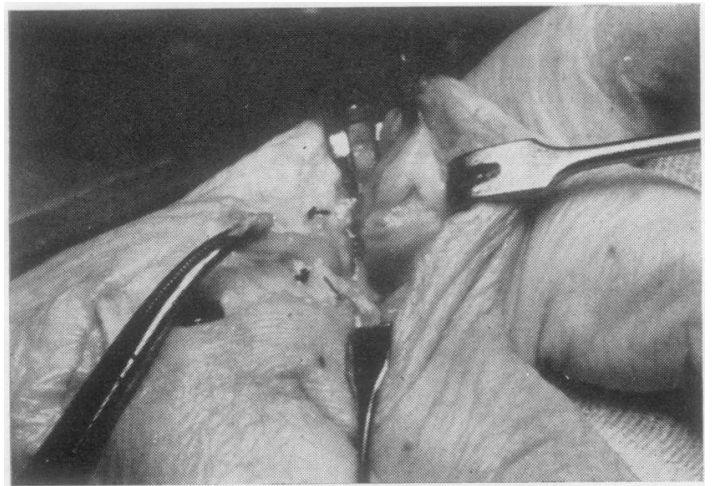

Fig. 5.-Same hand as in Fig. 1, showing tendinitis of an isolated wing tendon (held by the clamp).

between the base of the first phalanx and the lumbrical muscle and tendon in Fig. 1, were found in the rest of the cases explored.

All these changes disturb the delicate cooperation of the different parts of the intrinsic mechanism which should be able to function independently (Landsmeer, 1949). They also contribute to the development of different deformities. If the intrinsic tendons are adherent to the capsule with the muscles in a contracted position, the phenomenon will be more marked. Because the gliding movements of the tendons are impeded the tightness cannot be overcome even under anaesthesia without using great force.
Treatment.-We perform tenolysis of the intrinsic muscles in fingers with a positive Bunnell sign as a routine in metacarpophalangeal synovectomies. Severe changes in the intrinsic apparatus not amenable to complete removal may explain the persistent pain in some cases after metacarpophalangeal arthroplasty.

Comment.-Fig. 6 shows diagrammatically how expanding infiamed synovial tissue invades the capsule and the accessory ligament, which is a thin reinforcement of the capsule; it thus comes into contact with the overlying intrinsic tendons and adhesions may occur. Similar developments are common between the lateral slips and the capsule of the proximal interphalangeal joint in cases of swan-neck deformity (Nalebuff, Potter, and

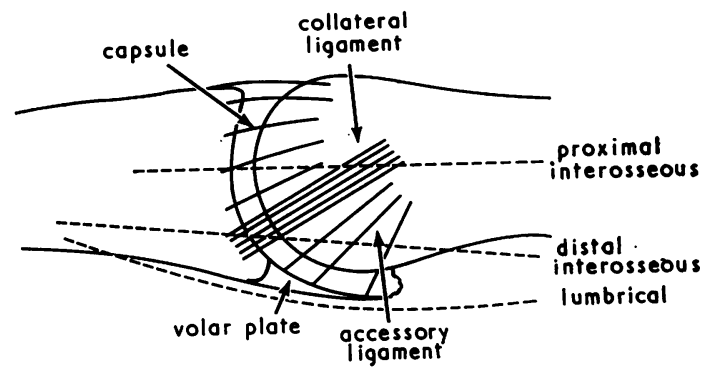

Fig. 6. -Diagram of the metacarpophalangeal joint. Interrupted lines indicate the course of the intrinsic muscles and tendons passing $\sigma$ the joint (Stack, 1962). 
Tomaselli, 1963) and in the carpal tunnel after previous inflammation. In more advanced cases the process will extend from the capsule to the overlying structures.

\section{Summary}

The positive Bunnell sign, indicating pathological tightness of the intrinsic tendons, can be caused by rheumatoid inflammation of the metacarpophalangeal joints. In mild cases adhesions develop between the capsule and the intrinsic tendons. In severe cases changes resembling rheumatoid nodules may block the natural movement of intrinsic expansion, thus simulating a contraction of the muscles.

\section{REFERENCES}

American Rheumatism Association: Rheumatism Review Committee (1966). Arthr. and Rheum., 9, 127.

Boyes, J. H. (1964). "Bunnell's Surgery of the Hand", 4th ed., revised by J. H. Boyes, pp. 332-334. Lippincott, Philadelphia.

Brewerton, D. A. (1957). Ann. rheum. Dis., 16, 183 (Hand deformities in rheumatic diseases).

Bunnell, S. (1953). J. Bone Jt Surg., 35-A, 88 (Ischemic contracture, local, in the hand).

Goldner, J. L. (1953). Ibid., 35-A, 115 (Deformities of the hand incidental to pathological changes of the extensor and intrinsic muscle mechanisms).

Harris, C., and Riordan, D. C. (1954). Ibid., 36-A, 10 (Intrinsic contracture in the hand and its surgical treatment.)

Kestler, O. C. (1949). Ann. rheum. Dis., 8, 42 (Histopathology of the intrinsic muscles of the hand in rheumatoid arthritis. A clinico-pathological study).

Landsmeer, J. M. F. (1949). Anat. Rec., 104, 31 (The anatomy of the dorsal aponeurosis of the human finger and its functional significance).

Marmor, L. (1962). Arthr. and Rheum., 5, 419 (Hand surgery in rheumatoid arthritis).

Nalebuff, E. A.; Potter, T. A., and Tomaselli, R. (1963). Ibid., 6, 289 (Surgery of swan neck deformity of the rheumatoid hand: a new approach).

Stack, H. G. (1962). J. Bone Jt Surg., 44-B, 899 (Muscle function in the fingers).

Strang, R. F. A., and Hueston, J. T. (1963). Med.J. Aust., 1, 427 (The role of surgery in the rheumatoid hand).

Altérations rhumatismales dans la région métacarpophalangienne comme cause du signe de Bunnell

\section{RÉSUMÉ}

Le signe de Bunnell positif, indiquant une raideur pathologique des tendons intrinsèques, peut être dû à l'inflammation rhumatismale des articulations métacarpophalangiennes. Dans des cas bénins des adhésions se forment entre la capsule et les tendons intrinsèques. Dans des cas sévères des lésions ressemblant aux nodules rhumatismaux peuvent bloquer le mouvement naturel de l'expansion intrinsèque, simulant ainsi une contraction des muscles.

\section{Alteraciones reumatoideas en la región metacarpofalan- giana como causa del signo de Bunnell}

\section{SUMARIO}

El signo de Bunnell positivo, indicando una tensión patológica de los tendones intrínsecos, puede deberse a la inflamación reumatoide de las articulaciones metacarpofalangianas. En los casos benignos se forman adhesiones entre la capsula y los tendones intrínsecos. En los casos más graves las lesiones se parecen a nódulos reumatoides y pueden bloquear el movimiento natural de expansión intrínseca, estimulando de este modo una contracción de los músculos. 